\title{
PENGARUH TAGIHAN PAJAK, PELAYANAN, DAN KEPATUHAN TERHADAP PENDAPATAN ASLI DAERAH PADA RESTORAN
}

\author{
Dhea Rizky ${ }^{1}$ \\ Rinaldi Rasidin ${ }^{2}$ \\ Venita Sofiani ${ }^{3}$ \\ ${ }^{1}$ Fakultas Ekonomi, Universitas Muhammadiyah Sukabumi \\ Email : dhearizky597@gmail.com \\ ${ }^{2}$ Fakultas Ekonomi, Universitas Muhammadiyah Sukabumi \\ Email : rinaldi.rasidin98@gmail.com \\ ${ }^{3}$ Fakultas Ekonomi, Universitas Muhammadiyah Sukabumi \\ Email : venitasofiani@ummi.ac.id
}

\begin{abstract}
Abstrak
Di Indonesia sampai saat ini pajak masih merupakan sumber penerimaan negara yang paling utama dalam memenuhi kehidupan dan sangat diperlukan adanya kesadaran dari berbagai pihak dalam penerimaan pajak terutama para wajib pajak untuk selalu patuh membayar kewajiban perpajakannya. Seperti sumber penerimaan dari pajak daerah yang sangat memiliki potensi yang cukup tinggi untuk pendapata asli daerah. Penelitian ini bertujuan untuk melihat pengaruh dari tagihan pajak, pelayanan dan kepatuhan terhadap pendapatan asli daerah pada restoran. Populasi dalam penelitia ini adalah pegawai/karyawan dari BPKD di Kota Sukabumi, teknik pengambilan sampel menggunakan probability sampling. Data penelitian ini menggunakan data primer secara langsung melalui kuesioner dan diolah menggunakan SPSS 24. Data diolah untuk menguji hipotesis menggunakan pendekatan asosiatif non parametrik hasil penelitian ini menunjukan bahwa pengaruh tagihan pajak pelayanan dan kepatuhan terhadap pendapatan asli daerah pada restoran dengan tingkat signifikasi $66 \%$ hal ini berarti tagihan pajak pelayanan dan kepatuhan berpengaruh signifikan terhadap pendekatan hasil daerah pada restoran.
\end{abstract}

Kata kunci: Pajak, Perpajakan, pajak kota sukabumi.

\section{PENDAHULUAN}

Di Indonesia sampai saat ini pajak-pajak masih merupakan sumber penerimaan negara yang paling utama dalam memenuh kehidupan negara. Terbukti bahwa manfaat pajak dapat kita rasakan dalam kehidupan sehari - hari seperti, fasilitas Kesehatan, pendidikan, transportasi sarana dan prasarana umum lainnya. Dan sangat diperlukan adanya kesadaran dari berbagai pihak dalam penerimaan pajak, terutama para wajib pajak untuk selalu taat membayar pajak. Menurut (Priantara, 2013) menyebutkan bahwa Pajak Daerah Secara Umum adalah kontribusi wajib kepada daerah yang terutang oleh orang pribadi atau badan yang bersifat memaksa berdasarkan undang - undang, dengan tidak mendapatkan imbalan secara langsung dan digunakan untuk keperluan daerah bagi sebesar - besarnya kemakmuran rakyat. Sumber penerimaan pajak daerah tersebut dapat diharapkan menjadi pembiayaan penyelenggaraan pemerintah, dan membangun daerah untuk meningkatkan kesejahteraan masyarakat.

Sumber penerimaan pajak daerah yang sangat memiliki potensi untuk Pendapatan Asli Daerah adalah Pajak Restoran. Dan untuk Kota Sukabumi Pajak Restoran menjadi salah satu Pajak Daerah yang berpotensi cukup besar yang dapat meningkatkan Penerimaan Pendapatan Asli Daerah. Dan sesuai dengan peraturan pemerintah Daerah No. 8 Tahun 2011 Tentang Pajak Restoran, Pajak Retoran ini dikenakan kepada orang pribadi atau badan atas pelayanan yang ada direstoran.

Seiring meningkatnya Restoran di Kota Sukabumi dikarenakan semakin berkembangnya bisnis Restoran yang ada di Kota Sukabumi yang telah banyak diminati dan menarik perhatian masyarakat luar kota maupun manca negara. Maka dengan ini Pemerintah Kota Sukabumi memanfaatkan fasilitas Restoran yang ada di Kota Sukabumi untuk mengupayakan kenaikan Pajak Daerah Kota Sukabumi melalui Pajak Restoran. 
Di Kota Sukabumi Pajak Daerah di pungut oleh Badan Pengelolaan Keuangan Daerah (BPKD) Kota Sukabumi. Terdapat 7 pajak yang dikelola oleh BPKD termasuk salah satunya pajak hotel dan pajak restoran. Berdasarkan Realisasi Penerimaan Pajak Restoran di Kota Sukabumi pada Tahun 2015-2018 seperti dibawah ini:

\section{Daftar Target dan Realisasi pajak Restoran pada BPKD Kota Sukabumi}

Tahun 2015 - 2018

\begin{tabular}{|c|c|c|c|}
\hline $\begin{array}{c}\text { Tahun } \\
\text { Anggaran }\end{array}$ & Target (Rp) & Realisasi & $\begin{array}{c}\text { Pencapaian } \\
(\boldsymbol{\%})\end{array}$ \\
\hline 2015 & Rp. $4.638 .625 .000,00$ & Rp. 5.419.167.051,00 & 116,83 \\
\hline 2016 & Rp. $5.736 .400 .000,00$ & Rp. $6.226 .709 .483,00$ & 108,55 \\
\hline 2017 & Rp. 7.507.800.000,00 & Rp. 9.442.812.010,00 & 125,77 \\
\hline 2018 & Rp. 7.507.800.000,00 & Rp. 9.442.155.298,00 & 125,76 \\
\hline
\end{tabular}

Dapat dilihat dari tabel yang ada diatas realisasi pajak restoran pada tahun 2015 - 2018 dapat mencapai target yang sangat tinggi dan telah ditetapkan, bahkan dari tahun ketahun mengalami kenaikan yang sangat baik terkecuali di tahun 2018 realisainya mengalami sedikit penurunan dalam penerimaan pajak nya dari tahun 2017, ini disebabkan karena adanya restoran yang tutup dengan tidak melaporkan kepada kantor BPKD Kota Sukabumi, karena tidak melakukan pembayar pajak. Akan tetapi dapat dilihat realisasi penerimaan pajak restoran cukup mengalami kenaikan yang sangat baik dan signifikan. Karena pengaruh dari bertambahnya wajib pajak restoran yang membayar pajaknya dengan potensi usaha yang semakin meningkat sistem kuliner yang ada di Kota Sukabumi.

Dibalik tingkat pencapaian dalam pelaksanaan penerimaan pajak restoran itu bukan berarti semuanya berjalan lancar, Adapun kendala dalam melaksanakan penerimaan pajak restoran tersebut dari kendala eksternal maupun internal yaitu keterbatasan sumber daya manusia (SDM) atau petugas penerimaan pajak yang kurang memadai, kurangnya pemahaman para petugas mengenai teknologi informasi dan belum adanya sanksi yang tegas terhadap Wajib Pajak yang tidak patuh. Dan kendala eksternalnya masih belum sepenuhnya memahami Pajak, berkurangnya objek pajak dan adanya keterlambatan atas penyampaian SPTPD (surat pemberitahuan pajak daerah) dari wajib pajak.

Kota Sukabumi mempunyai tujuan ke depan dalam hal mensejahterakan masyarakat dan kemandirian daerah. Sebagai upaya meningkatkan Pendapatan Asli Daerah (PAD) dengan menggali sumber - sumber pendapatan daerah, salah satu nya penggalian potensi pajak. Dengan penggalian potensi pajak juga butuh menumbuhkan rasa kesadaran masyarakat untuk dapat patuh dalam membayarkan kewajiban pajaknya karena sangat penting untuk meningkatkan target pajak yang akan dicapai, dengan menumbukan kesadaran juga ternyata masyarakat masih ada saja yang belum paham tentang membayarkan pajak nya. Dan untuk lebih meningkatkan potensi pajak dengan memberikan sanksi terhadap wajib pajak yang melakukan keterlambatan dalam membayarkan kewajiban nya sehingga dapat meningkatkan kepatuhan wajib pajak.

\section{KAJIAN PUSTAKA DAN PENGEMBANGAN HIPOTESIS Pajak Daerah}

Pajak Daerah yang selanjutnya disebut pajak adalah kontribusi wajib pajak kepada Daerah yang terutang oleh orang pribadi atau badan yang bersifat memaksa berdasarkan Undang - Undang, dengan tidak mendapatkan imbalan secara langsung dan digunakan untuk keperluan Daerah bagi sebesar - besarnya kemakmuran rakyat. Menurut (Lutfl, 2006), Pajak daerah, Ciri-ciri yang menyertai pajak daerah adalah Pajak Daerah berasal dari Pajak Negara yang diserahkan kepada daerah sebagai pajak daerah, penyerahan 
dilakukan berdasarkan Undang - Undang, Pajak Daerah di pungut oleh daerah berdasarkan kekuatan Undang - Undang dan atau peraturan hukum lainya (Anggoro, 2017).

Sedangkan Pengertian Pajak Menurut (Abut, 2017) menyatakan bahwa “ Pajak merupakan iuran kepada negara, yang dapat dipaksakan dan dihutangkan oleh wajib pajak membayarkan menurut peraturan, dengan tidak mendapatkan prestasi Kembali, yang langsung dapat ditunjuk dan gunanya adalah untuk membiayai pengeluaran umum berhubungan dengan tugas negara untuk menyelenggarakan pemerintah (Anggoro, 2017).

Fungsi Pajak Daerah Sebagaimana halnya pajak pusat, pajak daerah mempunyai peran penting dalam pelaksanaan fungsi negara/pemerintahan, baik dalam fungsi mengatur (regulatory), penerimaan (budgetary), retribusi (redistributive), dan lokasi sumber daya (resource allocation) maupun kombinasi antara keempatnya. Pada umunya fungsi pajak daerah lebih diarahkan untuk alokasi sumber daya dalam rangka penyediaan pelayaan kepada masyarakat, di samping fungsi regulasi untuk pengendalian. Sesuai hal tersebut, fungsi pajak daerah dapat dibedakan menjadi 2 (dua) fungsi utama, yaitu fungsi budgetary dan fungsi regulatory. Namun pembedaan ini tidaklah dikotomis (Anggoro, 2017).

\section{Surat Tagihan Pajak}

Undang - Undang KUP pasal 91 no. 20 menjelaskan bahwa, "Surat Tagihan Pajak adalah surat untuk melakukan tagihan pajak dan/atau sanksi administrasi berupa bunga dan atau denda." Definisi Surat tagihan pajak menurut Mardiasmo dalam Buku yang berjudul Perpajakan, menyatakan bahwa "Surat Tagihan Pajak (STP) adalah surat untuk melakukan tagihan pajak dan atau sanksi administrasi berupa bunga dan atau denda." Fungsi Surat Tagihan Pajak menurut Mardiasmo dalam buku perpajakan, menyatakan bahwa fungsi surat tagihan pajak adalah:

1. Sebagai koreksi atas jumlah pajak yang terutang SPT Wajib Pajak

2. Sarana mengenakan sanksi administrasi berupa denda atau bunga

3. Alat untuk menagih pajak.

Surat tagihan pajak adalah untuk melakukan tagihan pajak dan atau sanksi administrasi berupa bunga dan atau denda. Surat Tagihan Pajak diterbitkan apabila:

1. Pajak Penghasilan dalam tahun berjalan tidak atau kurang bayar.

2. Dari hasil penelitian terdapat kekurangan pembayaran pajak sebagai akibat salah tulis dan / atau salah hitung.

3. Wajib pajak dikenai sanksi administrasi berupa denda/bunga.

4. Pengusaha yang telah dikukuhkan sebagai pengusaha kena pajak, tetapi tidak membuat faktur pajak secara lengkap selain: a. idenitas pembeli atau b. identitas pembeli serta nama dan tanda tangan, dalam hal penyerahan dilakukan oleh pengusaha kena pajak pedagang eceran.

5. Pengusahaan kena Pajak melakukan faktur pajak tidak sesuai dengan masa penerbitan faktur pajak atau

6. Pengusaha kena pajak gagal berproduksi dan telah diberikan pengembalian pajak masukan.

Surat Tagihan Pajak mempunyai kekuatan hukum yang sama dengan surat ketetapan pajak. Pengenaan sanksi berkaitan dengan surat tagihan pajak diuraikan sebagai berikut:

Sanksi administrasi berupa bunga $2 \%$ per bulan paling lama 24 bulan dihitung sejak saat terutangnya pajak atau berakhirnya masa pajak, bagian tahun pajak, atau tahun pajak sampai dengan diterbitkannya surat tagihan pajak atas kuranng dibayar, atau hasil penelitian surat pemberitahuan yang menunjukkan pajak kurang bayar karena terdapat salah satu / salah tulis.

\section{Pajak Restoran}

Pajak Restoran adalah pajak atas pelayanan yang disediakan oleh restoran, Restoran adalah fasilitas penyedia makanan dan/atau minuman dengan dipungut bayaran, yang mencakup juga rumah makan, kafetaria, kantin, warung, bar, dan sejenisnya termasuk jasa boga / catering. Objek pajak restoran adalah pelayanan yang disediakan oleh restoran. Pelayanan yang disediakan restoran sebagaimana meliputi 
pelayanan penjualan makanan dan/atau minuman yang dikonsumsi oleh pembeli, baik dikonsumsi ditempat pelayanan maupun ditempat lain (Anggoro, 2017).

Subyek pajak restoran adalah orang pribadi atau badan yang membeli makanan dan/atau minuman di Restoran.sedangkan Wajib Pajak Restoran adalah orang pribadi atau badan yang mengusahakan Restoran. Pada pajak Restoran subjek pajak restoran dan wajib pajak restoran tidak sama, dimana konsumen yang membeli makanan dan atau minuman dari restoran merupakan subjek pajak yang membayar (menanggung) pajak sementara orang pribadi atau badan yang mengusahakan restoran bertindak sebagai wajib pajak yang diberi kewenangan untuk memunngut pajak dari konsumen (subjek pajak) dan melaksanakan kewajiban perpajakannya (Anggoro, 2017). Dasar Pengenaan Pajak Restoran adalah jumlah pembayaran yang diterima atau yang seharusnya diterima Restoran. Tarif Pajak Restoran ditetapkan paling tinggi sebesar 10\%. Tarif pajak restoran ditetapkan dengan Peraturan Daerah.

Dasar Pengenaan Pajak Restoran adalah jumlah pembayaran yang diterima atau yang seharusnya diterima restoran. Jika pembayaran dipengaruhi oleh hubungan istimewa, harga jual atau penggantian dihitung atas dasar harga pasar yang wajar pada saat pembelian makanan dan /atau minuman misalnya, hubungan istimewa adalah orang pribadi atau badan yang menggunakan jasa restoran dengan pengusaha restoran, baik langsung atau tidak langsung, berada dibawah pemilik perusahaan orang pribadi atau badan yang sama.

\section{Kualitas Pelayanan}

Pengertian kualitas pelayanan adalah ukuran seberapa bagus tingkat layanan yang diberikan sesuai degan ekspresi pelanggan. Pda umumnya harapan pelanggan dibentuk oleh pengalaman dan informasi lisan dan iklan (Tjiptojono, 2014). Menurut (Tjiptojono, 2014)ada beberapa hakekat pelayanan umum yaitu :

1. Meningkatkan mutu dan produktifitas pelaksanaan hakekat tugas dari instansi pemerintah di bidang pelayanan umum.

2. Mendorong upaya pengefektifan sistem dan tata laksana pelayanan sehingga pelayanan umum dapat diselenggarakan secara lebih berguna.

3. Medorong tumbuhnya kreatifitas prakarsa dan peran serta masyarakat dalam pembangunan serta meningkatkan kesejahtraan masyarakat.

Kualitas Pelayanan adalah sebagai ukuran seberapa bagus tingkat pelayanan yang akan digunakan sebagai pembanding antara pelayanan yang sudah diberikan oleh fiskus dengan apa yang diinginkan ole pelanggan wajib pajak. menurut (Andika, 2013) Kualitas Pelayanan adalah sebuah hasil yang harus dicapai dan dilakukan dengan sebuah tindakan. Namun tindakan tersebut tidak berwujud dan mudah hilang, namun dapat dirasakan dan diingat. Dampaknya adalah konsumen dapat lebih aktif dalam proses mengkonsumsi produk dan jasa suatu perusahaan.

Menurut (Tjiptono,2014), kualitas pelayanan adalah suatu keadaan dinamis yang berkaitan erat dengan produk, jasa, sumber daya manusia, serta proses dan lingkungan yang setidaknya melebihi kualitas pelayanan yang diharapkan. Menurut (Tjiptono, 2014)), definisi kualitas pelayanan ini adalah upaya pemenuhan kebutuhan yang dibarengi dengan keinginan konsumen serta ketetapan cara penyampaiannya agar dapat memenuhi harapan dan kepuasan pelanggan tersebut (Astuti, 2013).

\section{Kepatuhan Wajib Pajak}

Definisi kepatuhan wajib pajak menurut (Nurmantu, 2010) kepatuhan wajib pajak didefinisikan sebagai suatu keadaan dimana wajib pajak memenuhi semua kewajiban perpajakan dan melaksanakan hak perpajakannya, dan menurut (Sidik, 2010) bahwa kepatuhan memenuhi kewajiban perpajakan secara sukarela, dimana wajib pajak bertanggung jawab menetapkan sendiri kewajiban perpajakan kemudian secara akurat dan tepat waktu membayar dan melaporkan pajaknya tersebut.

Berdasarkan peraturan Menteri Keuangan Nomor 74/PMK.03/2012, bahwa kriteria kepatuhan wajib pajak adalah:

1. Tepat waktu dalam menyampaikan SPT;

2. Tidak mempunyai tunggakan pajak untuk semua jenis pajak, kecuali telah memperoleh izin untuk mengangsur atau menunda pembayaran pajak. 
3. Laporan keuangan diaudit oleh akuntan publik atau Lembaga pengawasan keuangan pemerintah dengan pendapat wajar tanpa pengecualian selama 3 (tiga) tahun berturut-turut.

4. Tidak pernah dipidana karena melakukan tindak pidana dibidang perpajakan berdasarkan putusan pengadilan yang telah mempunyai kekuatan hukum dalam jangka waktu 5 tahun terakhir.

\section{Pendapatan Asli Daerah}

Pendapatan Asli Daerah merupakan pendapatan yang diperoleh pemerintah daerah atas pelaksanaan kegiatan pemerintahan dan pelayanan kepada masyarakat, serta pemanfaatan sumber daya yang dimiliki pemerintah daerah. Pendapatan ini sering kali dijadikan indikator tangkat kemajuan suatu daerah. Daerah yang dianggap maju adalah daerah yang memiliki PAD yang tinggi. Hal ini dapat dimengerti karena dengan tingginya PAD yang dierima suatu daerah maka tingkat ketergantungan pemerintah daerah terhadap pemerintah pusat dalam hal pendanaan APBDnya akan semakin berkurang. Walaupun demikian, pemerintah daerah dilarang melakukan pemungutan - pemungutan kepada masyarakat yang dapat berakibat biaya ekonomi tinggi (high cost economy) yang pada akhirnya kurang mendukung dunia usaha/investasi. Selain itu, pemerintah daerah juga dilarang menetapkan peraturan daerah yang menghambat mobilitas penduduk (Anggoro, 2017).

Sumber - sumber yang bisa dikembangkan daerah yang dalam meningkatkan Pendapaan Asli Daerah:

1. Pajak Daerah, yaitu pajak - pajak yang ditentukan pemungutan dalam Peraturan Daerah, dan para pembayaran pajak (wajib pajak) tidak menerima imbalan secara langsung dari pemerintah daerah. Contoh pajak daerah adalah pajak kendaraan bermotor, pajak hiburan, pajak rumah makan/restoran, pajak iklan, dan lain sebagainya (Anggoro, 2017).

2. Retribusi Daerah yaitu pemungutan yang dikenakan kepada masyarakat yang dinikmati secara langsung fasilitas tertentu yang disediakan pemerintah daerah. Pemungutan juga harus dituangkan dalam peraturan daerah.contoh dari pendapatan ini adalah retribusi parkir, retribusi pasar, retribusi terminal. Dan sebagainya (Anggoro, 2017).

3. Hasil pengelolaan kekayaan daerah yang dipisahkan, yaitu pendapatan yang diperoleh dari pengelolaan badan - badan usaha milik daerah maupun Lembaga-lembaga lainya yang dimiliki pemerintah daerah (Anggoro, 2017).

4. Lain - lain PAD yang sah, yaitu pendapatan yang diperoleh pemerintah daerah selain tiga jenis pendapatan tersebut di atas. Pendapatan ini antara lain adalah hasil penjualan kekayaan daerah yang tidak dipisahkan, jasa giro, pendapatan bunga, keuntungan selisih nilai tukar rupiah terdapat mata uang asing, serta komisi, potongan ataupun bentuk penjualan dan/atau pengadaan barang dan/atau jasa oleh daerah (Anggoro, 2017).

\section{HIPOTESIS PENELITIAN}

Berdasarkan hasil penelitian terdahulu oleh (Lewasari, 2019) Ho di tolak dan Ha diterima dimana variable pajak hotel berpengaruh terhadap pendapatan asli daerah. Pada penelitian (Candrasari \& Ngumar, 2016) peningakatan untuk pajak hotel disebabkan penerimaan terbesar terjadi pada hotel bintang 3 sedangkan untuk pajak restoran disebabkan karena banyaknya pengembangan usaha serta minat suatu masyarakat untuk makan siap saji dipengaruhi tingkat perekonomian masyarakat, maka berdasarkan hipotesis dalam penelitian terdahulu di atas penelitian ini dibuat hipotesis sebagai berikut: Ho1: Diduga tidak terdapat pengaruh antara surat tagihan pajak terhadap pendapatan asli daerah. $\mathrm{H}_{\mathrm{a}} 1$ : Terdapat pengaruh anggaran surat tagihan pajak terhadap pendapatan hasil daerah pada restoran. $\mathrm{H}_{\mathrm{O}} 2$ : Tidak terdapat pengaruh antara pelayanan terhadap Pendapatan asli daerah pada restoran $\mathrm{H}_{\mathrm{a}} 2$ : Terdapat pengaruh antara pelayanan terhadap Pendapatan asli daerah pada restoran $\mathrm{H}_{\mathrm{o}} 3$ : Tidak terdapat pengaruh antara kepatuhan terhadap Pendapatan asli daerah pada restoran $\mathrm{H}_{\mathrm{a}} 3$ : Terdapat pengaruh antara kepatuhan terhadap Pendapatan asli daerah pada restoran $\mathrm{H}_{0} 4$ : Tidak terdapat pengaruh antara surat tagihan pajak, pelayanan dan kepatuhan terhadap pendapatan asli daerah pada restoran. $\mathrm{H}_{\mathrm{a}} 4$ : Terdapat pengaruh antara surat tagihan pajak, pelayanan dan kepatuhan terhadap pendapatan asli daerah pada restoran. 


\section{METODE PENELITIAN}

Dalam penelitian metode yang digunakan oleh peneliti ini yaitu metode penelitian Kuantitatif dengan pendekatan asosiatif. (Sugiyono, 2017) metode asosiatif digunakan untuk penelitian seberapa besar pengaruh surat tagihan pajak, pelayanan dan kepatuhan terhadap pendapatan hasil daerah pada restoran dalam penelitian ini populasinya adalah karyawan atau pegawai dari badan pengelolaan keuangan daerah (BPKD) kota sukabumi dan sampelnya yang digunakan berjumlah 45 orang. Teknik sampling yang digunakan adalah probability sampling yaitu sampel random sampling memberikan kesempatan pada semua anggota populasi untuk ditetapkan sebagai sampling dan yang menjadi sampel penelitian ini yaitu seluruh karyawan BPKD yang berjumlah 45 orang. Teknik pengumpulan data yang diperoleh dari data primer melalui kuesioner dan data sekunder yang didapatkan melalui Uji Validitas dan Uji Reabilitas.

\section{HASIL dan PEMBAHASAN}

\section{Karakteristik Responden}

Dalam mengumpulkan data pada penelitian ini salah satunya yaitun dengan membagikan kuesioner kepada responden yang terkait. Isi dari kuesioner tersebut yaitu mengenai Pengaruh Surat Tagihan Pajak, Pelayanan, Dan Kepatuhan Terhadap Pendapatan Asli Daerah Pada Sektor Pajak Hotel Dan Restoran. Adapun kuesioner yang dibagikan oleh peneliti kepada responden yaitu sebanyak 45. Dan Kembali sebanyak 45 juga. Karakteristik Responden yang ada pada penelitian ini yaitu:

\section{Karakteristik Responden Berdasarkan Usia}

\begin{tabular}{|c|c|c|}
\hline Usia & Jumlah & Presentase \\
\hline $20-25$ & 5 & $10 \%$ \\
\hline $25-30$ & 10 & $20 \%$ \\
\hline $30-35$ & 10 & $20 \%$ \\
\hline $35-50$ & 20 & $50 \%$ \\
\hline
\end{tabular}

\section{Uji Validitas}

Uji validitas menurut (Sugiyono, 2017), validitas berhubungan denga suatu perubahan mengukur apa yang seharunya diukur. Validitas dalam penelitian menyatakan derajat kecepatan alat ukur penelitian terhadap isi sebenarnya yang diukur. Uji validitas adalah uji yang diigunakan untuk menunjukan sejauh mana alat ukur yang digunakan dalam suatu mengukur apa yang diukur. Untuk mengetahui valid atau tidakna suatu kuesioner dalam penelitian, maka uji validitas mempunyai standar keputusan validitas, yaitu:

(1) Jika rhitung $\geq$ rtabel maka pernyataan kuesioner tersebut dikatakan valid.

(2) Jika rhitung $\leq$ rtabel maka pernyataan kuesioner tersebut dikatakan tidak valid.

rtabel diperoleh dari hasil perhitungan $\mathrm{df}=\mathrm{n}-2$, dimana $\mathrm{n}$ merupakan jumlah responden yang dijadikan sampel dalam peneltian ini, yaitu: 45 Orang dengan taraf signifikansi $10 \%(0,1)$. Maka dapat dilihat di lampiran, rtabel dari 45 dengan signifikansi $10 \%$ yaitu 0,294.

Hasil Uji Validitas Surat Tagihan Pajak (X1)
\begin{tabular}{|c|c|c|c|}
\hline No & rtabel & Rhitung & Keterangan \\
\hline 1 & 0,294 & 396 & Valid \\
\hline 2 & 0,294 & 543 & Valid \\
\hline 3 & 0,294 & 748 & Valid \\
\hline 4 & 0,294 & 710 & Valid \\
\hline
\end{tabular}




\begin{tabular}{|c|c|c|c|}
\hline 5 & 0,294 & 619 & Valid \\
\hline 6 & 0,294 & 654 & Valid \\
\hline 7 & 0,294 & 439 & Valid \\
\hline 8 & 0,294 & 541 & Valid \\
\hline
\end{tabular}

Hasil Uji Validitas Pelayanan (X2)

\begin{tabular}{|c|c|c|c|}
\hline No & rtabel & Rhitung & Keterangan \\
\hline 1 & 0,294 & 426 & Valid \\
\hline 2 & 0,294 & 448 & Valid \\
\hline 3 & 0,294 & 517 & Valid \\
\hline 4 & 0,294 & 545 & Valid \\
\hline 5 & 0,294 & 662 & Valid \\
\hline 6 & 0,294 & 617 & Valid \\
\hline 7 & 0,294 & 480 & Valid \\
\hline 8 & 0,294 & 652 & Valid \\
\hline
\end{tabular}

Hasil Uji Validitas Kepatuhan (X3)

\begin{tabular}{|c|c|c|l|}
\hline No & rtabel & Rhitung & Keterangan \\
\hline 1 & 0,294 & 236 & Tidak Valid \\
\hline 2 & 0,294 & 458 & Valid \\
\hline 3 & 0,294 & 263 & Tidak Valid \\
\hline 4 & 0,294 & 168 & Tidak Valid \\
\hline 5 & 0,294 & 225 & Tidak Valid \\
\hline 6 & 0,294 & 298 & Valid \\
\hline 7 & 0,294 & 339 & Valid \\
\hline
\end{tabular}

Hasil Uji Validitas Pendapatan Asli Daerah Pada Sektor Pajak Hotel Dan Restoran (Y)

\begin{tabular}{|c|c|c|c|}
\hline No & rtabel & Rhitung & Keterangan \\
\hline 1 & 0,294 & 296 & Valid \\
\hline 2 & 0,294 & 329 & Valid \\
\hline 3 & 0,294 & 426 & Valid \\
\hline 4 & 0,294 & 534 & Valid \\
\hline 5 & 0,294 & 339 & Valid \\
\hline 6 & 0,294 & 126 & Tidak valid \\
\hline
\end{tabular}

Dapat dilihat dari tabel hasil uji validitas Surat Tagihan Pajak (X1), hasil uji validitas Pelayanan (X2), hasil uji validitas Kepatuhan (X3) dan Hasil uji Pendapatan Asli Daerah Pada Sektor Pajak Hotel Dan Restoran (Y) diatas, bahwa semua item pernyataan pada kuesioner mengenai surat tagihan pajak (X1), Pelayanan (X2), Kepatuhan (X3), dan Pendapatan Asli Daerah Pada Sektor Pajak Hotel Dan Restoran (Y) tersebut dinyatakan valid karena nilai rhitung pada penelitian ini lebih banyak yang valid di bandingkan yang tidak valid yaitu lebih besar dari pada rtabel $(0,294)$. 


\section{Hasil Uji Reliabilitas}

Uji realibilitas dilakukan untuk mengetahui reliabel atau tidaknya suatu kuesioner yang diisi oleh responden. Apabila jawaban seseorang terhadap pertanyaan atau pernyataan dalam kuesioner konsisten, maka butir pertanyaan atau pernyataan bisa dikatakan reliabel atau andal. Untuk mengetahui reliabel atau tidaknya suatu kuesioner dalam penelitian, maka uji reliabilitas mempunyai kriteria, yaitu sebagai berikut:

(1) Jika $r_{1} \geq 0,6$ berarti reliabel.

(2) Jika $r_{1} \leq 0,6$ berarti tidak reliabel.

\begin{tabular}{|c|c|c|}
\hline \multicolumn{3}{|c|}{$\begin{array}{c}\text { Hasil Uji Reabilitas Surat Tagihan Pajak } \\
\text { Reliability Statistics }\end{array}$} \\
\hline & Cronbach's & \\
\hline & Alpha Based on & \\
\hline Cronbach's & Standardized & \\
\hline Alpha & Items & $\mathrm{N}$ of Items \\
\hline .787 & .791 & 8 \\
\hline
\end{tabular}

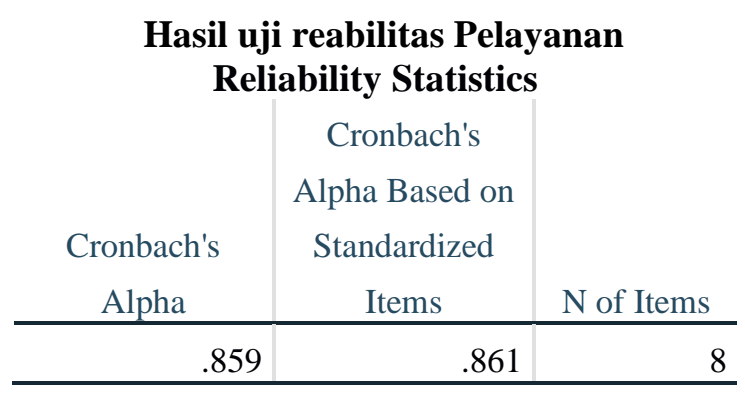

Uji reabilitas kepatuhan

\begin{tabular}{r|c|c}
\multicolumn{3}{c}{ Reliability Statistics } \\
& Cronbach's & \\
& Alpha Based on & \\
Cronbach's & Standardized & \\
Alpha & Items & N of Items \\
\hline .802 & .803 & 7 \\
\hline
\end{tabular}

\section{Hasil uji reabilitas pendapatan asli daerah pada sektor pajak hotel dan restoran \\ Reliability Statistics \\ Cronbach's \\ Alpha Based on \\ Cronbach's \\ Standardized \\ Alpha $^{\mathrm{a}}$

Items $^{\mathrm{a}} \quad \mathrm{N}$ of Items \\ .682

.681 \\ a. The value is positive due to a positive average covariance among items. This violates reliability model assumptions. You may want to check item codings.}




\section{Uji Asumsi Klasik \\ Uji Normalitas}

Uji normalitas digunakan untuk mengetahui atau melihat apakah data variabel bebas (X) dan variabel terikat (Y) berdistribusi normal atau tidak. Model regresi yang baik yaitu apabila pada variabel bebas ataupun terikat berdistribusi normal. Apabila variabel tersebut tidak berdistribusi normal, maka data hasil penelitian ini kurang untuk bisa menggambarkana karakteristik dari populasinya.

Untuk mengetahui suatu data berdistribusi normal atau tidak berdistribusi normal yaitu menggunakan analisis statistik Kolmogrov-Smirnov test dengan kriteria sebagai berikut:

(1) Jika sig $\geq 0,05$ berarti data berdistribusi normal.

(2) Jika sig $\leq 0,05$ berarti data tidak berdistribusi normal

\begin{tabular}{llr}
\multicolumn{3}{c}{ Hasil Uji Normalitas } \\
One-Sample Kolmogorov-Smirnov Test \\
Unstandardized \\
Residual
\end{tabular}

Dapat dilihat dari hasil uji normalitas one sample kolmogorov-smirnov test di atas, bahwa data semua variabel baik variabel bebas (X1) yaitu Pengaruh surat tagihan pajak, (X2) Pelayanan, (X3) Kepatuhan dan (Y) yaitu Terhadap Pendapatan Asli Daerah Pada Sektor Pajak Hotel dan Restoran terdistribusi secara normal, karena nilai signifikansi nya lebih dari 0,05. Dimana nilai sig nya yaitu sebesar 200.

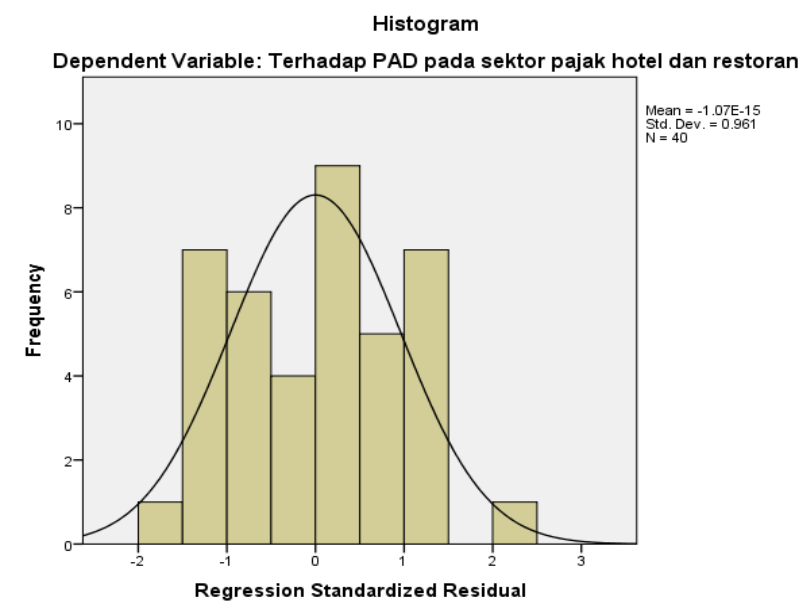

Dapat dilihat uji normalitas pada gambar histogram di atas, bahwa grafik yang ada pada histogram sudah mengikuti kurva berbentuk lonceng tidak lebih condong ke kiri dan ke kanan sehingga bisa dikatakan model regresi telah terdistribusi normal dan dapat dikatakan baik. 


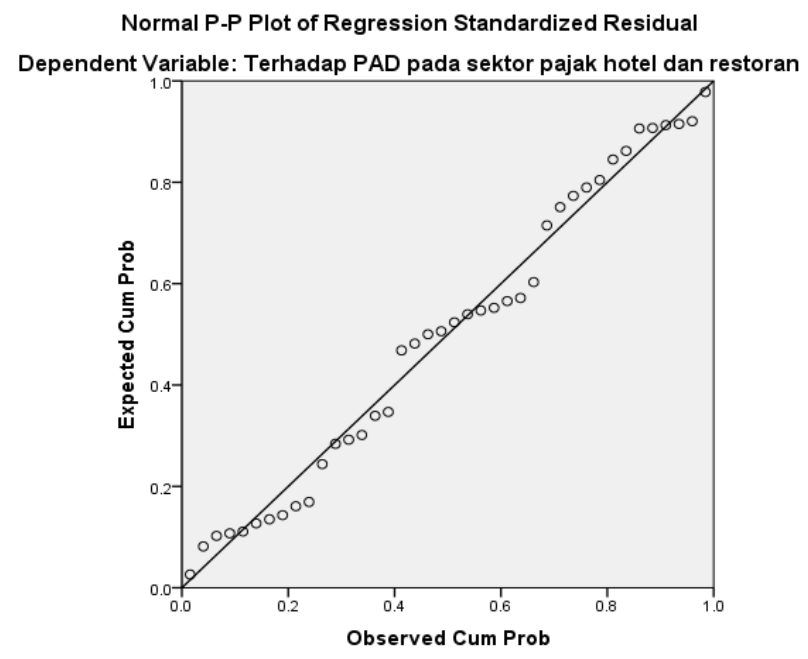

Dapat dilihat dari hasil uji normal P-Plot diatas, bahwa titik-titik data sudah menyebar di sekitar garis diagonalnya dan sudah mengikuti arah garis diagonalnya. Sehingga dapat disimpulkan data tersebut sudah memenuhi asumsi normalitas dan dapat melakukan pengujian lebih lanjut.

\section{Hasil Uji Multikoloinieritas}

Multikolinearitas bertujuaan untuk mengetahui atau melihat ada/tidaknya korelasi antar variabel bebas yang ada dalam penelitian ini, yaitu Pengaruh Surat Tagihan Pajak (X1), Pelayanan (X2), Kepatuhan (X3) dalam model regresi. Dalam melakukan uji multikolinearitas yaitu menggunakan Variance Inflationfactor (VIF), dengan kriteria sebagai berikut:

Jika tolerance di bawah angka 0,10 dan VIF > 10 maka terdapat gejala multikolinearitas.

\begin{tabular}{|c|c|c|c|c|c|c|c|c|}
\hline \multirow[b]{3}{*}{ Model } & \multicolumn{8}{|c|}{$\begin{array}{l}\text { Hasil Uji Multikolonieritas } \\
\quad \text { Coefficients }^{\mathrm{a}}\end{array}$} \\
\hline & & \multicolumn{2}{|c|}{$\begin{array}{l}\text { Unstandardized } \\
\text { Coefficients }\end{array}$} & \multirow{2}{*}{$\begin{array}{c}\text { Standardized } \\
\text { Coefficients } \\
\text { Beta } \\
\end{array}$} & \multirow[b]{2}{*}{$\mathrm{T}$} & \multirow[b]{2}{*}{ Sig. } & \multicolumn{2}{|c|}{ Collinearity Statistics } \\
\hline & & B & $\begin{array}{l}\text { Std. } \\
\text { Error }\end{array}$ & & & & Tolerance & VIF \\
\hline \multirow[t]{4}{*}{1} & (Constant) & 22.435 & 3.754 & & 5.977 & .000 & & \\
\hline & $\begin{array}{l}\text { Surat Tagihan } \\
\text { Pajak }\end{array}$ & .028 & .089 & .052 & .317 & .753 & .960 & 1.042 \\
\hline & Pelayanan & .032 & .077 & .072 & .419 & .678 & .892 & 1.120 \\
\hline & Kepatuhan & .070 & .062 & .196 & 1.127 & .267 & .863 & 1.159 \\
\hline
\end{tabular}

Dependent Variable: Terhadap PAD pada sektor pajak hotel dan restoran

Dapat dilihat dari hasil uji multikolinearitas di atas, bahwa tidak adanya korelasi antar Pengaruh Surat Tagihan Pajak (X1), Pelayanan (X2), Kepatuhan (X3) dalam model regresi, karena hasil perhitungan tolerance di atas angka 0,10 yaitu sebesar 0,960, 892, 863 dan hasil perhitungan VIF < 10 yaitu sebesar $1,042,1,120$ dan 1,159. Sehingga dalam penelitian ini, dapat disimpulkan tidak terdapat gejala multikolinearitas antar variabel bebas dalam model regresi. 


\section{Uji Heteroskedastisitas}

Uji heteroskedastisitas dilakukan untuk mengetahui atau melihat apakah dalam model regresi tidak terdapat ketidaksamaan varians dari residual satu pengamatan ke pengamatan lainnya. Model regresi yang baik disebut dengan homoskesdatisitas atau tidak terjadi heteroskedastisitas, karena variance dari residual satu pengamatan ke pengamatan lain tetap.

Apabila adanya pola seperti titik-titik yang membentuk pola tertentu pada grafik seperti bergelombang, melebar, kemudian menyempit maka telah terjadi heteroskedastisitas. Sedangkan apabila tidak adanya pola yang jelas, dan titik-titik menyebar di atas dan di bawah angka nol pada sumbu Y maka tidak terjadi heteroskedastisitas atau disebut dengan homoskesdatisitas.

Scatterplot

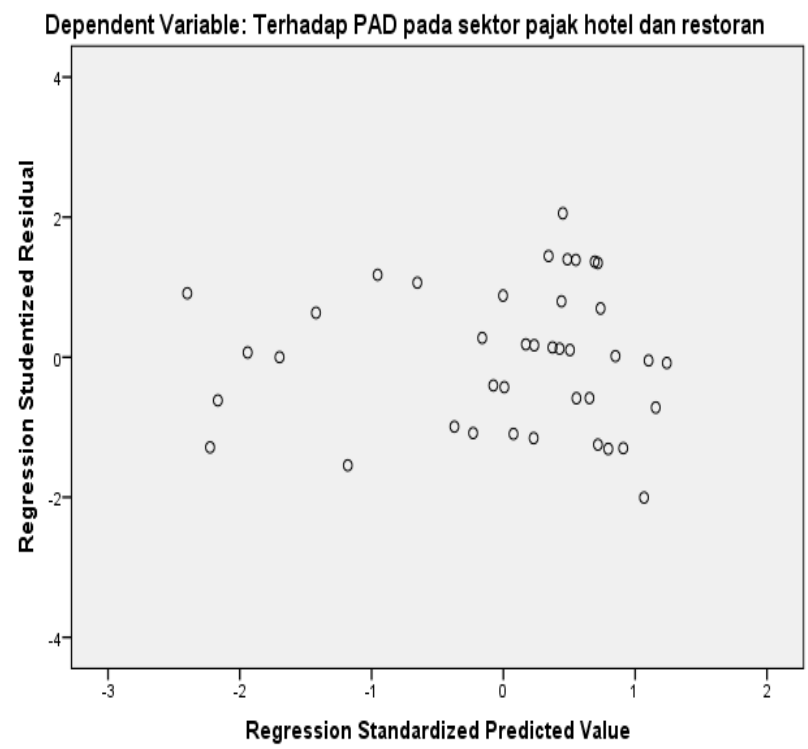

Grafik Scatter-Plot

Dapat dilihat dari grafik scatter-plot di atas, bahwa dalam penelitian ini tidak terjadi heteroskedastisitas atau disebut dengan homokedastisitas pada model regresi, karena tidak terdapat pola yang jelas dan titik-titik pada grafik scatter-plot tersebut menyebar di atas dan di bawah angka nol pada sumbu Y.

\section{Analisis Regresi Linear Berganda}

Analisis regresi linear berganda digunakan untuk menguji pengaruh beberapa variabel bebas dalam penelitian ini yaitu Pengaruh Surat Tgihan Pajak (X1), Pelayanan (X2), Kepatuhan (X3) terhadap satu variabel terikat yaitu terhadap Pendapatan Asli Daerah Pada Sektor Pajak Hotel dan Restoran (Y).

\begin{tabular}{|c|c|c|c|c|c|c|c|c|}
\hline \multicolumn{9}{|c|}{ Coefficients $^{\mathrm{a}}$} \\
\hline \multirow{2}{*}{\multicolumn{2}{|c|}{ Model }} & \multicolumn{2}{|c|}{$\begin{array}{l}\text { Unstandardized } \\
\text { Coefficients }\end{array}$} & \multirow{2}{*}{$\begin{array}{c}\text { Standardized } \\
\text { Coefficients } \\
\text { Beta }\end{array}$} & \multirow[b]{2}{*}{$\mathrm{T}$} & \multirow[b]{2}{*}{ Sig. } & \multicolumn{2}{|c|}{$\begin{array}{l}\text { Collinearity } \\
\text { Statistics }\end{array}$} \\
\hline & & $\mathrm{B}$ & Std. Error & & & & Tolerance & VIF \\
\hline \multirow[t]{4}{*}{1} & (Constant) & 22.435 & 3.754 & & 5.977 & .000 & & \\
\hline & $\begin{array}{l}\text { Surat Tagihan } \\
\text { Pajak }\end{array}$ & .028 & .089 & .052 & .317 & .745 & .960 & 1.042 \\
\hline & Pelayanan & .032 & .077 & .072 & .419 & .678 & .892 & 1.120 \\
\hline & Kepatuhan & .070 & .062 & .196 & 1.127 & .267 & .863 & 1.159 \\
\hline
\end{tabular}

a. Dependent Variable: Terhadap PAD pada sektor pajak hotel dan restoran 
Berdasarkan persamaan regresi linear berganda, maka dapat dilihat dari hasil uji regresi linear berganda di atas, bahwa persamaan regresi linear berganda pada penelitian ini, yaitu sebagai berikut: $\mathrm{Y}=22.434+028 \mathrm{X}_{1}+032 \mathrm{X}_{2}+070 \mathrm{X} 3+\varepsilon$

Keterangan:

$\mathrm{Y}=$ Pendapatan Asli Daerah Pada Sektor Pajak Hotel dan Restoran

$\mathrm{X}_{1}=$ Surat Tagihan Pajak

$\mathrm{X}_{2}=$ Pelayanan

$\mathrm{X}_{3}=$ Kepatuhan

\section{Hasil Uji t}

Uji t dalam penelitian ini dilakukan untuk mengetahui pengaruh satu variabel bebas terhadap variabel terikat, seperti uji t dalam penelitian ini yaitu dilakukan untuk mengetahui Surat Tagihan Pajak (X1) terhadap Pendapatan Asli Daerah Pada Sektor Pajak Hotel dan Restoran (Y) dan untuk mengetahui pengaruh Pelayanan (X2) terhadap terhadap Pendapatan Asli Daerah Pada Sektor Pajak Hotel dan Restoran (Y) dan untuk mengetahui pengaruh kepatuhan (X3) Terhadap Pendapatan Asli Daerah Pada Sektor Pajak Hotel dan Restoran (Y). Apabila nilai signifikansi < 0,05 maka terdapat pengaruh yang signifikan antara variabel bebas terhadap variabel terikat secara parsial. Dan apabila nilai signifikansi > 0,05 maka tidak terdapat pengaruh yang signifikan antar variabel bebas terhadap variabel terikat secara parsial. Hasil uji t dalam penelitian ini yaitu sebagai berikut:

\begin{tabular}{|c|c|c|c|c|c|c|c|c|}
\hline \multicolumn{9}{|c|}{ Coefficients $^{\mathrm{a}}$} \\
\hline & & \multicolumn{2}{|c|}{$\begin{array}{l}\text { Unstandardized } \\
\text { Coefficients }\end{array}$} & \multirow{2}{*}{$\begin{array}{c}\text { Standardized } \\
\text { Coefficients } \\
\text { Beta }\end{array}$} & \multirow[b]{2}{*}{$\mathrm{T}$} & \multirow[b]{2}{*}{ Sig. } & \multicolumn{2}{|c|}{$\begin{array}{l}\text { Collinearity } \\
\text { Statistics }\end{array}$} \\
\hline \multicolumn{2}{|c|}{ Model } & $\mathrm{B}$ & Std. Error & & & & Tolerance & VIF \\
\hline \multirow[t]{4}{*}{1} & (Constant) & 22.435 & 3.754 & & 5.977 & .0 .00 & & \\
\hline & $\begin{array}{l}\text { Surat Tagihan } \\
\text { Pajak }\end{array}$ & .028 & .089 & .052 & 2.317 & .045 & .960 & 1.042 \\
\hline & Pelayanan & .032 & .077 & .072 & 2.419 & .078 & .892 & 1.120 \\
\hline & Kepatuhan & .070 & .062 & .196 & 2.127 & .067 & .863 & 1.159 \\
\hline
\end{tabular}

a. Dependent Variable: Terhadap PAD pada sektor pajak hotel dan restoran

Berdasarkan uji t pada table di atas diketahui bahwa surat tagihan pajak berpengaruh signifikan terhadap pendapatan asli daerah pada restoran dimana nilai signifikasi sebesar 0.045 lebih kecil dari 0.05 yang berarti terdapat pengaruh.

Berdasarkan uji t pada table di atas diketahui bahwa pelayanan tidak berpengaruh signifikan terhadap pendapatan asli daerah pada restoran dimana nilai signifikasi sebesar 0.078 lebih besar dari 0.05 yang berarti tidak berpengaruh.

Berdasarkan uji t pada table di atas diketahui bahwa kepatuhan tidak berpengaruh signifikan terhadap pendapatan asli daerah pada restoran dimana nilai signifikasi sebesar 0.067 lebih besar dari 0.05 yang berarti tidak berpengaruh.

Uji F

Uji F dilakukan untuk mengetahui pengaruh semua variabel bebas secara bersama-sama terhadap variabel terikat yang dimasukan dalam model regresi. seperti uji $\mathrm{F}$ dalam penelitian ini yaitu dilakukan untuk mengetahui pengaruh secara bersama-sama Surat tagihan Pajak (X1) pelayanan (X2) dan kepatuhan (X3) terhadap Pendapatan Asli Daerah pada sektor pajak hotel dan restoran (Y). Apabila nilai signifikansi $<0,05$ maka terdapat pengaruh yang signifikan secara bersamasama antara variabel bebas terhadap variabel terikat. Dan apabila nilai signifikansi > 0,05 maka tidak terdapat pengaruh yang signifikan secara bersamasama antar variabel bebas terhadap variabel terikat. 
Hasil uji F dalam penelitian ini yaitu sebagai berikut:

\begin{tabular}{|c|c|c|c|c|c|c|}
\hline \multicolumn{7}{|c|}{ ANOVA $^{a}$} \\
\hline Model & & Sum of Squares & Df & Mean Square & $\mathrm{F}$ & Sig. \\
\hline \multirow[t]{3}{*}{1} & Regression & 5.723 & 3 & 1.908 & 2.768 & $.019^{\mathrm{b}}$ \\
\hline & Residual & 89.377 & 36 & 2.483 & & \\
\hline & Total & 95.100 & 39 & & & \\
\hline
\end{tabular}

Berdasarkan uji t pada table di atas diketahui bahwa surat tagihan pajak berpengaruh signifikan terhadap pendapatan asli daerah pada restoran dimana nilai signifikasi sebesar 0.019 lebih kecil dari 0.05 yang berarti terdapat pengaruh.

\section{Uji Koefisien Determinasi}

Uji koefisien determinasi dilakukan untuk mengukur seberapa besar kemampuan variabel independen (variabel bebas) yaitu Surat tagihan pajak (X1), Pelayanan (X2) dan Kepatuhan (X3) dalam menerangkan variasi variabel devenden (variabel terikat) yaitu Pendaptan Asli Daerah Pada Sektor Pajak Hotel dan Restoran (Y). Nilai koefisien determinasi yaitu antara nol dan satu. Hasil dari uji koefisien determinasi dapat dilihat sebagai berikut:

\begin{tabular}{lc|c|c|c} 
& & \multicolumn{2}{c}{ Model Summary } \\
Model & $\mathrm{R}$ & R Square & $\begin{array}{c}\text { Adjusted R } \\
\text { Square }\end{array}$ & $\begin{array}{c}\text { Std. Error of the } \\
\text { Estimate }\end{array}$ \\
\hline 1 & $.245^{\mathrm{a}}$ & .660 & -.018 & 1.57565 \\
\hline a. Predictors: (Constant), Kepatuhan, Surat Tagihan Pajak, Pelayanan
\end{tabular}

Berdasarkan uji koefisien determinasi diatas menunjukan bahwa nilai koefisien determinasi (Kd) Sebesar 660 atau sama dengan 66\% sehingga dapat disimpulkan bahwa surat tagihan pajak pelayanan dan kepatuhan hanya memberikan pengaruh pendapatan asli daerah pada restoran yaitu sebesar $66 \%$ dan sisanya sebesar $44 \%$ yang dipengaruhi oleh variable yang tidak diteliti.

\section{PEMBAHASAN}

Berdasarkan hasil perhitungan uji hipotesis yaitu uji t variable surat tagihan pajak (X1) dengan nilai sigifikasinya $0,045<0,05$ maka $\mathrm{H}_{01}$ ditolak dan $\mathrm{H}_{\mathrm{a} 1}$ diterima. Sehingga dapat disimpulkan Surat tagihan pajak (X1) berpengaruh positif dan signifikan terhadap Penghasilan Asli Daerah pada restoran(Y). Berdasarkan penelitian dan uji hipotesis denga uji t menggunakan SPSS. Bahwa variabel surat tagihan pajak (X1) memiliki nilai signifikasi 0,045 < 0,05. Dengan ini dapat disimpulkan bahwa Ho ditolak Ha diterima. Yang berarti terdapat pengaruh antara variabel surat tagihan pajak terhadap pedapatan asli daerah.

Berdasarkan hasil perhitungan uji hipotesis yaitu uji variabel pelayanan (X2) dengan nilai signifikasinya $0,078>0,05$ maka $\mathrm{H}_{02}$ ditolak dan $\mathrm{H}_{\mathrm{a} 2}$ diterima. Sehingga dapat disimpulkan bahwa pelayanan (X2) tidak berpengaruh positif dan signifikan terhadap pendapatan asli daerah pada restoran (Y). Berdasarkan penelitian dan uji hipotesis denga uji t menggunakan SPSS. Bahwa variabel Pelayanan (X2) memiliki nilai signifikasi 0,078 > 0,05. Dengan ini dapat disimpulkan bahwa Ho ditolak Ha diterima. Yang berarti tidak terdapat pengaruh antara variabel pelayanan terhadap pedapatan asli daerah.

Berdasarkan hasil perhitungan uji hipotesis yaitu uji t variabel kepatuhan (X3) dengan nilai sigifikasinya 0,067>0,05 maka $\mathrm{H}_{02}$ ditolak dan $\mathrm{H}_{\mathrm{a} 2}$ diterima. Sehingga dapat disimpulkan bahwa kepatuhan (X3) tidak berpengaruh positif dan signifikan terhadap pendapatan asli daerah pada restoran (Y). Berdasarkan penelitian dan uji hipotesis denga uji t menggunakan SPSS. Bahwa variabel Pelayanan (X2) memiliki nilai signifikasi 0,067 > 0,05. Dengan ini dapat disimpulkan bahwa Ho ditolak Ha diterima. Yang berarti tidak terdapat pengaruh antara variabel kepatuhan terhadap pedapatan asli daerah. 
Berdasarkan penelitian hasil dari uji hipotesis yaitu uji F dengan menggunakan software SPSS 24 for windows, di ketahui bahwa nilai $\mathrm{F}$ hitung hasil perhitungan uji $\mathrm{F}$ hitung untuk surat tagihan pajak (X1), pelatyanan (X2) dan kepatuhan (X3) dengan nilai sigifikasinya karena $0,019<0,05$ maka $\mathrm{H}_{03}$ ditolak dan $\mathrm{H}_{\mathrm{a} 3}$ diterima. Sehingga dapat disimpulkan surat tagihan pajak (X1), pelayanan (X2) dan kepatuhan (X3) secara bersama-sama atau secara simultan berpengaruh positif dan signifikan terhadap pendapatan asli daerah pada restoran (Y). Berdasarkan penelitian dan uji hipotesis denga uji t menggunakan SPSS. Bahwa variabel Pelayanan (X2) memiliki nilai signifikasi 0,019>0,05. Dengan ini dapat disimpulkan bahwa Ho ditolak Ha diterima. Yang berarti terdapat pengaruh antara variabel surat tagihan pajak, pelayanan dan kepatuhan terhadap pedapatan asli daerah.

Berdasarkan penelitian dari uji koefisien determinasi menyatakan bahwa nilai $\mathrm{R}^{2}$ atau $\mathrm{R}$ sguare dalam penelitian ini yaitu sebesar 660 atau $66 \%$. Hal ini berarti bahwa Surat tagihan pajak (X1), pelayanan (X2) dan Kepatuhan (X3) hanya memberikan pengaruh pendapatan asli daerah pada restoran (Y) yaitu sebesar $66 \%$ dan sisanya sebesar $44 \%$ yang dipengaruhi oleh variabel yang tidak diteliti. Karena nilai $\mathrm{R}^{2}$ di bawah 0,50 atau cenderung mendekati nilai 0 sehingga dapat disimpulkan bahwa kemampuan variabelvariabel independen (variabel bebas) dalam menjelaskan variasi variabel dependen (variabel terikat) sangat terbatas.

Dalam hasil penelitian (Lewasari, 2019) Pajak Hotel merupakan salah satu komponen terpenting dalam meningkatkan Pendapatan Asli Daerah (PAD) guna pembangunan ekonomi berdasarkan hasil penelitian menghasilkan pernyataan bahwa pajak restoran berpengaruh positif terhadap pendapatan asli daerah (PAD), yang artinya Ketika hotel dan restoran yang berada pada suatu kota menghasilkan pendapatan yang baik itu artinya pendapatan asli daerah pun akan semakin baik pula, dan dalam hasil penelitian (Rachmawati, 2015) bahwa surat tagihan pajak daerah dan sanksi administrasi berpengaruh terhadap kepatuhan wajib pajak. Hal ini karena wajib pajak akan membayar jika surat tagihan pajak diterbitkan secara bersama-sama dengan adanya sanksi administrasi. Dan dalam hasil penelitian (Sulatika, 2017) bahwa Pemahaman Peraturan Pajak restoran, omset restoran dan kualitas pelayanan berpengaruh signifikan terhadap Kepatuhan Wajib Pajak.

\section{KESIMPULAN}

Berdasarkan hasil pembahasan maka dapat di tarik kesimpulan akhir Surat Tagihan Pajak berpengaruh positif dan signifikan terhadap Pendapatan Asli Daerah pada Restoran. karena adanya faktor dari wajib pajak yang mendapatkan adanya surat tagihan pajak atas tunggakan nya sehingga wajib pajak dengan cepat membayarkan tunggakan tersebut, dan dari hasil pembahasan dari pelayanan bahwa tidak terdapat pengaruh terhadap pendapatan asli daerah. Hal ini karena masih adanya faktor pelayanan yang masih kurang bagus, kurang menarik konsumen atau pelanggan yang datang, dan dari hasil pembahasan mengenai kepatuhan bahwa kepatuhan tidak dapat pengaruh terhadap pendapatan asli daerah, karena adanya faktor keterlambatan dari pihak wajib pajak dalam membayarkan pajak, Hasil penelitian keseluruhan dari variabel surat tagihan pajak, pelayanan dan kepatuhan sehingga dapat disimpulkan surat tagihan pajak, pelayanan dan kepatuhan, secara bersama - sama berpengaruh positif dan signifikan terhadap pendapatan asli daerah pada restoran. Hal ini menunjukan bahwa para wajib pajak akan patuh dalam membayarkan pajak nya jika suatu pelayananya disetiap restoran/pelayanan pajak ditingkatkan, maka akan adanya peningkatan dalam pendapatan asli daerahnya.

\section{SARAN}

1. Saran teoritis pada penelitian ini harus dengan lebih memahami mengenai pajak daerah, lebih spesifik tidak keseluruhan, agar penelitianya lebih fokus.

2. Saran praktis pada penelitian ini badan pengelolaan keuangan harus bisa menegur atau memberikan sanksi yang sangat tegas terhadap wajib pajak yang tidak mematuhi kewajiban dengan mengeluarkan teguran dan surat peringatan. 


\section{REFERENSI}

Abut. (2017) . pajak daerah dan retribusi daerah. UB Press. http://www.ubpress.ub.ac.id

Andika, H. (2013) Pengaruh Pengetahuan Pajak, Kualitas Pelayanan dan Pemeriksaan Pajak terhadap Kepatuhan Wajib Pajak Restoran.. Journal of Chemical Information and Modeling, 53(9), 16891699. https://doi.org/10.1017/CBO9781107415324.004

Anggoro, D. D. (2017). Pajak Daerah dan Retribusi Pajak Daerah (D. D. Anggoro (ed.); 1st ed.). UB Press. http://www.ubpress.ub.ac.id

Astuti, P. T. (2013). Analisis Efektifitas Penerimaan Pajak Restoran, Pajak Hotel dan Pajak Penerangan Dalam Peningkatan Pendapatan Asli Daerah. Journal of Chemical Information and Modeling, 53(9), 1689-1699. https://doi.org/10.1017/CBO9781107415324.004

Candrasari, A., \& Ngumar, S. (2016). Kontribusi Pajak Hotel dan Restoran Terhadap Teningkatan Pendapatan Asli Daerah Kota Surabaya (Contribution of Hotel and Restaurant Tax to Increase of Revenue of Area of Surabaya City). Jurnal Ilmu Dan Riset Akuntansi, 5(2), 1-22. https://ejournal.stiesia.ac.id/jira/article/viewFile/1631/1592

Lewasari, S. (2019). Pegaruh pajak hotel dan pajak Restoran dan Pajak Hiburan Terhadap Pedapatan Asli Daerah.http:///repository.radentan.ac.id.

Lutfl, S. dalan. (2006). Pajak daerah dan Retribusi Daerah. UB Press. http://www.ubpress.ub.ac.id

Nurmantu, S. (2010). Moralitas, Budaya dan kepatuhan pajak. website www.cvalfabeta.com email:alfabetabdg@yahoo.co.id,ISBN,IKAPI

Priantara Diaz, 2013. Perpajakan Indonesia. Edisi 2 Revisi. Penerbit Mitra Wacana Media. Jakarta.

Rachmawati, R. L. (2015). Pengaruh surat Tagihan Pajak Daerah terhadap Kepatuhan Wajib pajak Restoran. 5, 2. perpajakan.studentjournal.ub.ac.id

Sari, A. C. (2016). Kontribusi Pajak Hotel dan Restoran Terhadap Peningkatan Pendapatan Asli Daerah Kota Surabaya. value: Jurnal Ilmu dan Riset Akuntansi VOL.5 No.2

Sidik, M. (2010). Moralitas, Budaya dan kepatuhan pajak. website www.cvalfabeta.com email:alfabetabdg@yahoo.co.id,ISBN,IKAP.

Sugiyono. (2017). Metode Penelitian. Alfabeta Bandung.

Sulatika, R. (2017). Pengaruh Pemahaman Peraturan Omset, Kualitas Pelayanan Dan Sanksi Terhadap Kepatuhan Wajib Pajak. JOM Fekon Vol. 4 No. 1

Tjiptojono. (2014). Pengaruh kualitas pelayanan terhadap Kepuasan Pelanggan. jurnal managemen. Vol.14 No.2. 